\title{
Spatial Reference Patterns as a Point of Hegemonic Struggle: A Case Study of Biotechnology Journals in Latin America
}

\author{
Bárbara Rivera-López and Manuel Matas Luci
}

\section{Introduction}

1 Although, in the context of a knowledge society, science has (allegedly) reached a state of globalization, the textual production of knowledge is subjected to Western-hegemony practices (Paasi, 2005, 2015). These practices are situated in historical processes of colonization that have contributed to the stabilization and selection of certain dominant narratives and certain ways of knowing over others (Péloquin, 2017).

2 As a consequence, there exist uneven writing spaces which generate differentiated knowledge production conditions that affect the legitimization and dissemination of knowledge according to the place where it is produced (Paasi, 2005, 2015). This puts some territories in the centre-UK, US, and West European countries-and others on the periphery, which are collectively referred to as the Global South. In this dynamic, the "centre" determines the topics that are worth investigating, the language (English), the formats used to communicate knowledge, what is considered high-quality science, and the validity of some ways of knowing over others.

It is well-known that English is currently the dominant language involved in the production, reproduction, and circulation of textual knowledge (Hwang, 2005; Short, Boniche, Kim and Li Li, 2001; Tietze and Dick, 2013). Although English permits increased global interaction, using it as a lingua franca introduces social consequences. This phenomenon is not just a technical matter permitting communication, but rather also contributes to linguistic dominance as a form of Western hegemony (Canagarajah 2002; Paasi, 2015). It reflects various positions of language users, privileges certain worldviews 
and interests, enables the explanation of certain ideas and not others, shapes certain meanings, and constructs shared understandings (Hwang, 2005; de Sousa Santos, 2016; Tietze and Dick, 2013). While this may seem like a hopeless situation, points of hegemonic struggle can occur when "different meaning systems or languages meet and vie for influence, and expose opportunities to question and challenge what is being taken for granted" (Tietze and Dick, 2013, p. 125).

4 The current academic knowledge production conditions in Latin America are contradictory. On one hand, academic knowledge is understood as a public good which has established the proper conditions for the development of Acceso Abierto (Alperín \& Fischman, 2015; Aguado-López and Vargas Arbeláez, 2016). In this respect, since 1997, the SciELO network has created an infrastructure that has promoted a collaborative publishing model and added value to science produced in the region. On the other hand, the current trend in some institutions and governments is to approach the impact and visibility challenge through the adoption of Northern practices. This has caused a narrow understanding of internationalization as publication in journals included in Web of Science (WoS) or Scopus commercial platforms (Alperín \& Rozemblum, 2017; Vasen \& Lujano Vilchis, 2017).

5 Considering that knowledge is "constructed, communicated, and evaluated mostly in the form of written statements, which is to say publications" (Paasi, 2009, p. 222), it is relevant to analyze the role of language in the production of textual knowledge accounts (Tietze and Dick, 2013).

6 Through the performance of a case study, we compare the spatial citation patterns of two highly cited Biochemistry journals indexed in the SciELO network: Crop Breeding and Applied Biotechnology (Brazil) and Biotecnología en el Sector Agropecuario y Agroindustrial (Colombia). We interpret our findings under the consideration that referencing in languages other than English opens meanings and enriches discussion, constituting itself as a point of hegemonic struggle. Finally, we seek to contribute to the description of knowledge production practices in Latin America in its relationship with languages besides English (in this case, Spanish and Portuguese).

\section{Method}

The aim of the present research is to identify spatial patterns in 141 references contained in six articles written in Spanish and Portuguese. This is performed by identifying the country of origin of each reference and, with this data, a country to link matrix can be built for later flow analysis.

The journals-Crop Breeding and Applied Biotechnology (published in Brazil) and Biotecnología en el Sector Agropecuario y Agroindustrial (published in Colombia)-were chosen due to their high impact in SciELO. The six articles were chosen randomly: three articles from Brazil and three from Colombia.

9 The rationale behind the selection of Biochemistry is its translatable nature. This means that the discipline has higher levels of collaboration and even physical mobility of scientists due to its global approach, worldwide topics, and the broad adoption of English in knowledge production and communication (Unesco, 2005; Paasi, 2005; Sonnenwald, 2007). 
Respecting research strategy, a multi-descriptive case study meets the needs of the present investigation, as it provides an in-depth and insightful description of the phenomenon. Furthermore, a case study allows understanding of the complexity of the context in which these patterns occur (Yin, 2012; Biggam, 2015).

11 Regarding the analysis, it is primarily qualitative in nature because it is concerned with the description and understanding of cases as ends in themselves (Singh, 2011). Nevertheless, there is also a quantitative aspect which "has a mechanistic, nonjudgmental component in the form of statistical inference" (Howe, 1998, as cited in Robson, 2011, p. 163). Therefore, we use a sequential transformative design.

In order to improve the efficiency of data collection, we developed a simple Python script to obtain information about publications and their authors from Google Scholar, using email and affiliation information for country assignment. This automated process goes over each publication in the references list, following an algorithm for country assignment. The algorithm:

1. searches all available publication metadata including author's full name;

2. gets all authors' full names and iterates over each one in order to acquire author metadata, focusing on email and affiliation;

3. searches the two characters of the domain from the email field by pattern (when the data collection of this metadata was successful), for example, ".us" for US, ".cl" for Chile; and

4. at the same time, searches for author's affiliation and geocodes it using Google Maps Geocoding API.

13 The country assignment for each author considers first the email domain information-in the case of no available information, the code is set to "not found." Each reference inherits the most frequent country of the authors. If the frequency of multiple countries in the same reference is even, then the reference inherits all of these countries.

14 After having all main articles and their references with a country of origin set, another script processes that information and creates a link matrix between the countries who cite and who are cited. Each link represents one instance of that country relationship. Aggregating those instances, it is possible to obtain a final data structure for analysis: frequencies or flows of citation between countries.

\section{Findings and Discussion}

Before going any further, it is relevant to establish the authors' positionality, which provides context for the interpretation of the findings. Both authors are non-native English speakers and early career researchers from Chile. One of the authors experienced marginalization; invisibilization; and feelings of rejection, failure, and anxiety, attributable to being subject to hegemonic processes while studying in the Global North.

Furthermore, while interpreting the present results it is important to clarify that not all of the authors affiliated with the Global North were born in those countries; nevertheless, while working in these spaces they had access to resources and networks which allowed them to adjust the dominant academic format (Tietze \& Dick, 2013).

The journals analyzed-Crop Breeding and Applied Biotechnology, and Biotecnología en el Sector Agropecuario y Agroindustrial-are published in Brazil and Colombia, respectively. The 
authors of the six articles (from now on, "main articles") have Spanish and Portuguese as their native languages.

Results show that main articles mostly cite publications from the same country. The top five countries cited by main articles published in Brazil were Brazil, Germany, US, UK, and Canada. In the case of main papers published in Colombia, the top 5 countries were Colombia, Brazil, Spain, Iran, and Argentina (Table 2).

Table 1. Country of Origin Frequency of Crop Breeding and Applied Biotechnology (published in Brazil)

\begin{tabular}{|l|l|l|}
\hline Country of reference & Frequency & Percentage \\
\hline Brazil & 27 & $36.49 \%$ \\
\hline Germany & 6 & $8.11 \%$ \\
\hline US & 5 & $6.76 \%$ \\
\hline UK & 4 & $5.41 \%$ \\
\hline Canada & 3 & $4.05 \%$ \\
\hline
\end{tabular}

Table 2. Country of Origin Frequency of Biotecnología en el Sector Agropecuario y Agroindustrial (published in Colombia)

\begin{tabular}{|l|l|l|}
\hline Country of reference & Frequency & Percentage \\
\hline Colombia & 30 & $37.04 \%$ \\
\hline Brazil & 7 & $8.64 \%$ \\
\hline Spain & 6 & $7.41 \%$ \\
\hline Not found & 4 & $4.49 \%$ \\
\hline Iran & 3 & $3.70 \%$ \\
\hline
\end{tabular}

Regarding language, 54.31\% of the references of Biotecnología en el Sector Agropecuario y Agroindustrial (published in Colombia) are written by native Spanish speakers, while $36.49 \%$ of the references of Crop Breeding and Applied Biotechnology (published in Brazil) are written by native Portuguese speakers.

Biotechnology spatial citation patterns and their relationship with language has not previously been the focus of research. We believe this trend stems from the fact that the discipline is considered a Natural Science, a universal field which is conditioned by different publication practices than the ones of Social Science and Humanities. For example, acceptance is determined by the perceived level of the 'hardness' of science. There is also more page space available to publish because journals appear each week, and newcomers can take their first steps in the publishing market because they publish in large groups with highly respected authors. Lastly, writing in the natural sciences is 
topic-neutral, while in social sciences, publications are topic-sensitive. (Fuller, 2012, as cited in Paasi, 2015).

Despite the above features characterizing Biotechnology publishing spaces, they are also subject to Western hegemony practices (Paasi, 2015). Under that consideration, Biotechnology knowledge produced in Latin America is part of the periphery in which parochial or "national" science is produced.

While hegemony practices may seem unwavering, our results allow us to introduce nuance to this perspective. The authors of the six analyzed articles are legitimizing knowledge produced in Spanish and in Portuguese. They are interconnecting their ideas with others in Latin America and creating representational designs that "are the fundamental basis of all academic and scholarly knowledge work. They give tangible form to fields of interest. They are found objects that precede all new intellectual work and new knowledge representation" (Cope and Kalantzis, 2014, pp. 11-12).

Thus, the spatial citation patterns identified in the present research allow us to interpret them as areas of hegemonic struggle, where the use of English is resisted by using resources that are constructed in other languages.

\section{Conclusion}

English predominance (among other Western-hegemony practices) has contributed to the homogenization of academic knowledge production and the creation of unequal publication spaces. In consequence, it should be "questioned in the name of both pluralism and academic freedom" (Paasi, 2013, p. 1); this exercise allows "contesting what is currently understood to count as interesting and important knowledge and what is worthy of publication" (Tietze and Dick, 2013, p. 125).

By approaching this hegemony, we make it subject to debate, challenging it and exposing it. Since power relations are not fixed, they can be resisted and transformed (Passi, 2015).

We interpret spatial citation patterns with high percentage of references in Spanish and Portuguese as points of resistance to what Paasi (2015) identifies as the standardization and homogenization of scientific practice. In other words, these non-English references create a space where "hegemony of the center is resisted/disrupted at a local level" (Tietze and Dick, 2013, p. 125).

27 As a result, Latin American journals should not be considered as peripheral, but as a rich publication and discussion space, where "a balanced and active exchange of ideas take place, which are more beneficial for science than unidirectional flows" (Paasi, 2015, p. 34). This characteristic is highly valued in a context where Latin American journals are adopting Northern logics of production and evaluation (Alperín \& Rozemblum, 2017). SciELO could use the potentiality and richness of Latin American journals to return to its original mission and create an alternative of the hegemonic practice of textual production. This could be the first step to creating a publication space where every actor has the right to speak and the power to define its own position. 


\section{BIBLIOGRAPHY}

\section{References}

Aguado-López. E., \& Vargas Arbaláez, E. (2016). “Reapropiación del conocimiento y descolonización: el acceso abierto como proceso de acción política del sur." Rev. Colom. Soc., 39(2): 69-88.

Alperín, J. P., \& Fischman, G. (Eds.) (2015). Hecho en Latinoamerica. Acceso Abierto, Revistas Académicas e Innovaciones Regionales. Buenos Aires: CLACSO.

Alperín, J. P., \& Rozemblum, C. (2017). “La reinterpretación de visibilidad y calidad en las nuevas políticas de evaluación de revistas científicas." Revista Interamericana de Bibliotecología, 40(3): 231241.

Biggam, J. (2015). Succeeding with your master's dissertation: a step-by-step handbook. 3rd Ed. Maidenhead: Open University Press.

Canagarajah, S. (2002). A Geopolitics of Academic Writing. Pittsburgh, PA: University of Pittsburgh. de Sousa Santos, B. (2016). "Epistemologies of the South and the future." From the European South, 1: 17-29.

Cope, B., \& Kalantzis, M. (2014). "Changing knowledge ecologies and the transformation of the scholarly journal.” In: A. Phillips and B. Cope (Eds.), The future of the academic journal: 9-83. 2nd Ed. Oxford: Chandos.

Hwang, K. (2005). “The Inferior Science and the Dominant Use of English in Knowledge Production. A case study of Korean Science and Technology." Science Communication, 26(4): 390427.

Paasi, A. (2005). "Globalization, academic capitalism and the uneven geographies of international journal publishing spaces.” Environment and Planning, 37(6): 769-789.

Paasi, A. (2009). "Political boundaries.” International Encyclopaedia of Human Geography, 8: 217-227.

Paasi, A. (2013). "Fennia: positioning a 'peripheral' but international journal under the condition of academic capitalism.” Fennia-International Journal of Geography, 191(1): 1-13.

Paasi, A. (2015). “Academic Capitalism and the Geopolitics of Knowledge.” In: J. Agnew, V. Mamadouh, A.J. Secor, \& J. Sharp (Eds.), The Wiley Companion to Political Geography, 509-523. London: Wiley.

Péloquin, C. (2017). "Postcolonial Technoscience and Development Aid. Insights from the political economy of locust control expertise.” In D. Tyfield, R. Lave, S. Randalls \& C. Thorpe (Eds), The Routledge Handbook of the Political Economy of Science. New York: Routledge.

Robson, C. (2011). Real World Research. 3rd Ed. Chichester: Wiley.

Singh, I. (2011). Thematic Analysis [Lecture to MsC Social Research Methods], MY421: Qualitative Research Methods. London School of Economics, 25 November. 
Short, J.R., Boniche, A., Yeong, K. and Li Li, P. (2001). "Cultural Globalization, Global English, and Geography Journals.” The Professional Geographer, 53(1): 1-11.

Slaughter, S. \& Rhoades, G. (2004). Academic Capitalism and the New Economy. Baltimore/London: The John Hopkins University Press.

Sonnenwald, D. H. (2007). "Scientific Collaboration: A Synthesis of Challenges and Strategies." Annual Review of International and Technology, 41: 643-681.

Unesco (2005). Towards Knowledge Societies: UNESCO World Report. Paris: Unesco publishing.

Vasen, F., \& Lujano Vilchis, I. (2017). “Sistemas nacionales de clasificación de revistas científicas en América Latina: tendencias recientes e implicaciones para la evaluación académica en ciencias sociales." Revista Mexicana de Ciencias Políticas y Sociales, 62(231): 199-228.

Tietze, S., \& Dick, P. (2013). “The Victorious English Language: Hegemonic Practices in the Management Academy.” Journal of Management Inquiry, 22(1): 122-134.

Yin, R.K. (2012). Applications of Case Study Research. London: Sage.

\section{ABSTRACTS}

Anglophone hegemony in knowledge production processes has been long acknowledged. Academic capitalism (Slaughter and Leslie, 2004) and its neoliberal rationalities, the dominant narratives within the colonial ventures, and a dominant and unreflective use of English in the production of textual knowledge have produced uneven structures in the academic publishing space, a homogenization of the concept of 'international' (Paasi 2005, 2015; Tietze and Dick, 2013; Péloquin, 2017). The contribution of the present research to this debate is the identification of points of hegemonic disruption in Latin America. We performed a case study on six articles written in Spanish and Portuguese of two Latin American Biotechnology journals with the purpose of identifying their spatial reference pattern. Findings show a high use of references in Spanish and Portuguese $(54,31 \%$ and $36.49 \%$, respectively. We interpret complex linguistic referencing patterns - this is citing in languages other than English - as an environment that opens meanings and enriches discussion. Moreover, we conceive Latin America as a space of hegemonic struggle against English homogenization in Science, and the SciELO platform as the infrastructure with the potential to (hopefully) transform the current academic status quo.

INDEX

Keywords: Latin America, English as a lingua franca, geopolitics of knowledge

\section{AUTHORS}

\section{BÁRBARA RIVERA-LÓPEZ}

Universidad Mayor, Chile

barbara.rivera.lo@gmail.com

(corresponding author) 
MANUEL MATAS LUCI

Public Analytics Lab, Center for Advanced Research on Education, University of Chile, Chile manuel.matas@ciae.uchile.cl 